\title{
Internationalizing sustainable agriculture education
}

\author{
Michelle S. Schroeder-Moreno, ${ }^{a},{ }^{*}$ Department of Crop Science, North Carolina State University

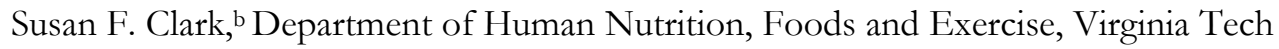 \\ Carmen J. Byker, ${ }^{\mathrm{c}}$ Department of Health \& Human Development, Montana State University

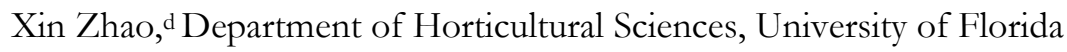

Submitted 6 December 2011 / Revised 2 March, 13 April and 25 April 2012 / Accepted 2 May 2012 /

Published online 27 May 2012

Citation: Schroeder-Moreno, M. S., Clark, S. F., Byker, C. J., \& Zhao, X. (2012). Internationalizing sustainable agriculture education. Journal of Agriculture, Food Systems, and Community Development, 2(3), 55-68.

http://dx.doi.org/10.5304/jafscd.2012.023.007

Copyright (C) 2012 by New Leaf Associates, Inc.

\begin{abstract}
Integration of international learning experiences into sustainable agriculture (SA) educational programs represents a unique and effective approach to help students improve their global awareness and citizenship, intercultural communication, problem-solving skills, and career development. While there are challenges to establishing

\footnotetext{
a, * Corresponding author: 2406 Williams Hall, Department of Crop Science, NC State University, Raleigh, NC 27695 USA; +1-919-513-0085; michelle schroeder@ncsu.edu

b 202 Wallace Annex, Department of Human Nutrition, Foods and Exercise, Virginia Tech, Blacksburg, VA 24061 USA; +1540-231-8768; sfclark@,vt.edu

c 222 Romney Gym, Department of Health \& Human Development, Montana State University, Bozeman, MT 59717 USA; +1-406-994-1952; carmen.byker@montana.edu

d 1301 Fifield Hall, Department of Horticultural Sciences, University of Florida, Gainesville, FL 32611 USA; +1-352273-4773; zxin@ufl.edu
}

Volume 2, Issue 3 / Spring 2012 international educational activities in emerging SA programs, the benefits of providing students with a global perspective to the worlds' food systems far exceed those challenges. This paper formalizes key considerations and diverse approaches for developing student-centered international educational opportunities for sustainable agriculture that have been assembled from literature research and from the collective experiences of the authors. A holistic approach is described, beginning with developing strong international partnerships built on reciprocity and understanding the diversity of international learning opportunities and development considerations; establishing learning outcomes and assessment; and appreciating current opportunities and challenges. While many of the experiences and examples come from land-grant universities (LGUs), enhancing a global perspective to all types of SA programs at various institutions is vital for preparing future food system leaders to advance sustainable agriculture in the global community. The information in this paper is valuable for SA 
educators interested in developing new international educational opportunities and also may stimulate further communication about shared pedagogical strategies related to international SA education.

\section{Keywords}

agroecology, curriculum, global education, international collaborations, land-grant universities, study abroad, sustainable agriculture

\section{Introduction: Why Is a Global Perspective to SA Education Necessary?}

The 21 st century poses a number of challenges for the long-term sustainability of agriculture and food systems on both local and international scales. In addition to land-grant universities' (LGUs) core missions of education, discovery, and outreach, there is also an emerging emphasis on the development of global citizens. The National Academy of Sciences (NAS) 2009 report calls for fundamental reform in agricultural education to keep pace with the rapidly changing world (NAS, 2009). A key recommendation states the need to expose the next generation of agriculture students to diverse international opportunities to remain competitive in our changing environment. However, there are philosophical, pedagogical, and practical challenges facing institutions of higher learning as they endeavor to create global citizens. Exactly how we institutionalize purposeful international learning experiences in sustainable agriculture education programs will be pivotal in educating students for global citizenship in our world's food system.

Growing student interest in sustainable agriculture (SA) and the broader food system has resulted in a diversity of undergraduate programs developed nationwide in the last decade, especially at LGUs. On August 3, 2011, in conjunction with the $4^{\text {th }}$ National Sustainable Agriculture Education Association (SAEA) Conference, a pre-conference workshop was held at the University of Kentucky in Lexington that brought SA programs at LGUs together for an extended, focused dialogue. This full-day workshop brought faculty and students together to discuss the "State of Sustainable Agriculture Education at Land-Grant Universities," which focused on sharing the successes and challenges, and identifying national needs, in SA undergraduate programming at LGUs. Six universities were represented (North Carolina State University, University of California-Davis, University of Kentucky, University of Missouri, University of Vermont, and Virginia Tech), with one to three faculty members and several undergraduate students from participating programs. A number of key areas for SA education were discussed in this workshop, including the emergence, shared successes, and challenges of SA programs at LGUs; the importance of civic and community engagement in SA education; the implicit inclusion of values into SA pedagogy; and the importance of efforts to internationalize SA curriculum. Workshop participants and other contributing authors have transformed the dialogue within each of these critical areas of SA education into other articles in this issue. This particular article will focus on the importance of efforts to internationalize SA education. Many of the authors on this manuscript have developed new SA courses and curricula, and together they have 15 years of collective experience developing and teaching or co-teaching a diversity of SA courses internationally. In this paper, we offer both suggestions from our shared experiences and a synthesis of the literature research in this topic as a way to discuss successful strategies and stimulate further discussion for internationalizing SA education.

While we acknowledge that specific program names may differ (e.g., sustainable agriculture, agroecology, organic agriculture, and food systems), they will be collectively referred to as sustainable agriculture $(\mathrm{SA})$ programs in this paper since they share similar interdisciplinary, systems-based curricula. Many of these SA programs were designed to offer diverse, multidisciplinary curricula that emphasize experiential and hands-on learning, and stimulate critical thinking about real-world food system challenges (Parr, Trexler, Khanna, \& Battisti, 2007). While students in these programs are exposed to a diversity of field and classroom experiences, such as farm visits, student farm work, SA research, and community engagement, much of the focus is placed on learning about their local and the U.S. food system (Parr et al., 2007). Much less curriculum emphasis and fewer directed educa- 
tional opportunities exist to increase students' awareness of global food systems and their sustainable agricultural challenges.

The National Association of State Universities and Land-Grant Colleges (NASULGU) calls for expanding and strengthening study abroad and other international experiences within institutes of higher education (NASULGC, 2004, 2007). Many SA programs nationwide are new and in the initial curricular development stages, where adding an international course may be viewed as a possible future step after the program has become more established. While we acknowledge challenges to establishing new international activities, we believe that strategically incorporating international learning opportunities into SA curricula would further enhance students' critical thinking skills and reinforce a systems-level perspective. From our experience, international learning opportunities may also challenge agriculture and non-agriculture students to understand the site-appropriate SA practices that balance specific environmental resources, cultural knowledge, and socioeconomic capital. Such transformative international experiences result in more knowledgeable, civically engaged, and globally responsible citizens once students graduate (Lewin, 2009; NASULGC, 2007). When these added-value learning opportunities are integrated across teaching, discovery, and engagement, students as well as faculty may benefit. In this article we assert that international educational opportunities are essential for the development of SA graduates who are prepared to address the complex agricultural and food-system challenges in a growing and changing world.

While international learning experiences are becoming important in higher education and the number of students applying to study-abroad experiences is increasing, the number of agricultural students consistently makes up the smallest percentage of those going abroad, estimated at just 1 percent of the total student study-abroad population, according to data from 2008-2009 (Institute of International Education [IIE], 2010). Study-abroad programs are known for building confidence, increasing problem-solving skills, and creating global awareness for agricultural students (Acker, 1999). Our experiences suggest that international learning opportunities present multifaceted benefits to SA students for professional development. They help shape global careers and lead to an enhanced worldview, increased self-esteem and self-confidence, more favorable perceptions of intercultural sensitivity, greater cultural awareness, and increased global perspectives, global mindedness, and personal growth (Dwyer \& Peters, 2004). Additionally, study-abroad experiences have been shown to improve students' communication skills (VanDerZanden, Haynes, Nonnecke, \& Martin, 2007).

While the student benefits from international experiences are becoming evident, we acknowledge that a number of challenges may exist for their development. We have observed that time and effort commitments may be substantial at times for faculty, with significant efforts required to develop international partnerships, design the international itinerary, deal with student recruitment and logistics, and carry out various educational activities internationally. From our experience, it is also important to understand how international learning activities can be assessed and valued toward faculty scholarship and promotion at individual institutions and within specific departments or disciplines.

This paper presents the raison d'etre for internationalizing SA education and describes diverse ways for developing student-centered international educational opportunities. From our diverse experiences, we discuss key considerations in developing international partnerships and diverse international learning opportunities from study abroad to service-learning, novel approaches for using technology, and establishing learning outcomes and assessment, as well as current challenges and opportunities. While much of our experience and examples are derived from LGUs, enhancing a global perspective to all types of SA programs at various institutions is vital. We believe the information in this paper can be valuable for educators in sustainable agriculture, agroecology, and related food-system programs who are interested in developing new international educational opportunities. It is also expected to stimulate further communication about shared pedagogical strategies related to international SA education. 


\section{International Learning Begins with Developing Authentic International Partnerships}

Of critical importance for facilitating international SA education experiences is developing collaborative and democratic partnerships among individual faculty, institutions, international organizations, and/or communities. Heffernan and Poole (2005) prioritize three fundamental elements in sustainable international education partnerships: communication, trust, and commitment. International partnerships should rely upon democratic participation that establishes relationships that are mutually beneficial for both student education and the international community (Lewin, 2009). From the beginning of the partnership, clear roles should be defined to ensure that all participants understand the expectations and level of commitment needed for achieving the given purpose of the international SA education program (Tubbeh \& Williams, 2010). These collaborative learning environments should embody mutuality and reciprocity and maintain a high degree of accountability between students, faculty, universities, and the international site. Clear communication among international partners and institutions is essential to developing strong, mutually beneficial collaborations (Etling \& McGirr, 2005) when working through global partnerships. Moreover, from our experience, greater trust and sustained collaboration among international partners has been realized when the U.S. faculty partner speaks or learns to speak the language of the international partner, especially when abroad. Establishing international partnerships takes time and often involves developing specific agreements among institutions to facilitate partnerships (Etling \& McGirr, 2005). While patience and persistence are necessary virtues, we have observed that successful international partnerships often exceed the originally projected benefits for the faculty, students, community, and institutions involved.

There are several avenues for developing international sustainable education partnerships. The United States Department of Agriculture's publication, Education and Training Opportunities in Sustainable Agriculture, highlights the diversity of possible partners for universities, including forprofit, nonprofit, and nongovernmental organiza- tions (NGOs), private entities, and other universities (Thompson, 2009). While funding is a challenge for any program, it is necessary to facilitate partnership development and exchange of faculty and students. An increasing number of private and federal funding agencies endorse collaborative efforts for international training and education initiatives.

\section{Development of and Considerations for International Learning in Sustainable Agriculture}

We believe the breadth and depth of international SA learning activities can extend beyond the traditional study-abroad experience. Oftentimes study abroad is perceived as the only means to develop international experiences, when there is a diversity of other approaches to develop global learning opportunities and perspectives, especially for agricultural students (Brooks, Frick \& Bruening, 2006). In a survey of 49 LGUs, more than half reported offering a selection of international opportunities with agricultural content and focus (Bruening \& Shao, 2005). They also reported having a wide range of formal (international curricula or course-based) and informal (cocurricular) pedagogies available, including the standard study-abroad programs. Furthermore, a number of these international learning experiences included varying degrees of service-learning. Service-learning and engaging with communities while abroad often makes international experiences more meaningful to students and makes longlasting impact on their professional development (Tonkin \& Quiroga, 2004). Building on these general-international learning experiences described in Bruening \& Shao (2005), we have developed a series of diverse international experiences and considerations specific for SA education (table 1).

From our observations, a range of programs exist within institutional SA study-abroad and service-learning experiences. Yet it is a current challenge for students and educators to access them, as the offerings are not consistent and there is no all-inclusive platform to conduct a search. We have compiled various examples of successful international SA courses nationwide and described their program characteristics in more depth in 


\section{Table 1. Diverse Approaches of International Sustainable Agriculture Educational Experiences and Characteristics}

\begin{tabular}{|c|c|}
\hline Examples & Characteristics \\
\hline Exchange programs & $\begin{array}{l}\text { Partnering institutions from two different countries establish a reciprocal relationship where } \\
\text { students exchange places and develop knowledge and skills by integrating into the host } \\
\text { institution's academic program. }\end{array}$ \\
\hline In-class activities & $\begin{array}{l}\text { Case studies, international guest speakers, and discussions facilitate a cursory understanding of } \\
\text { other cultures and can supplement or, if resources are limited, serve as a substitute for } \\
\text { international experiences. }\end{array}$ \\
\hline Internships & $\begin{array}{l}\text { An avenue to gain paid or unpaid work experience abroad and the specialized skill sets needed for } \\
\text { employment in the global market. }\end{array}$ \\
\hline Service-learning & $\begin{array}{l}\text { A pedagogical strategy that incorporates community service, specific learning objectives, and } \\
\text { methods for student reflection. }\end{array}$ \\
\hline Study abroad & $\begin{array}{l}\text { Students travel to a foreign country, often hosted by international higher education institution(s), to } \\
\text { study subject matter from a specified academic program for an established period of time (ranging } \\
\text { from one week to multiple years). }\end{array}$ \\
\hline Video and technology & $\begin{array}{l}\text { Courses use interactive technology and videoconferencing to connect students at universities } \\
\text { around the world. Topics pertinent to the course subject matter are presented, discussed, and } \\
\text { debated virtually. An example of this is the Global Seminar consortium } \\
\text { (http://www.globalseminar.org). }\end{array}$ \\
\hline $\begin{array}{l}\text { Alternative SA work } \\
\text { and learning } \\
\text { experiences }\end{array}$ & $\begin{array}{l}\text { Some programs include: } \\
\text { Agriventure (http://www.agriventure.com) } \\
\text { Global Service Corps (http://www.globalservicecorps.org) } \\
\text { Living Routes (http://www.livingroutes.org) } \\
\text { World-wide Opportunities on Organic Farms (WWOOF; http://www.wwoof.org ) }\end{array}$ \\
\hline
\end{tabular}

table 2 (in the Appendix). While this list is not exhaustive, it provides a good representation of international SA courses offered primarily for undergraduate students and taught on a consistent basis. While it is difficult to describe a specific typology of these study-abroad and service-learning experiences, many tend to be shorter ( 1 to 4 weeks), are offered during the summer or spring break, are taught at an introductory level, and attract students from diverse backgrounds and disciplines. Additionally, a few of these courses are offered collaboratively between and among different U.S. institutions, allowing institutions and collaborating faculty to share expertise, student recruitment, and development efforts. This can benefit students by offering a wider range of international SA experiences and enhanced exposure to diverse perspectives than one institution can offer alone. A central network and working consortium for advertising and communicating about international SA programs is currently lacking and in our opinion would greatly assist faculty sharing curricula materials, discussing pedagogies, and forming collaborations, in addition to providing a primary site for students to search for these opportunities.

With deliberate consideration about the variety of ways in which SA international education can occur, a faculty member can plan a program that may create opportunities for significant gains in student learning through improving students' understanding of international communities and developing a perspective of the global food system. Although we acknowledge that it may be daunting to develop an international learning experience from scratch, we have developed a number of key considerations for developing successful SA international experiences (table 3). It is important to recognize that many of these development activities may need to take place a year before actually implementing them. While we realize that development may require a substantial investment of time, innovative approaches in international education may improve the quality of undergraduate $\mathrm{SA}$ education as well as provide the foundation 
Table 3. Key Considerations and Action Items for Faculty in Developing International SA Education Experiences

\begin{tabular}{|c|c|}
\hline Key Considerations & Action Items \\
\hline Realize and research options & $\begin{array}{l}\text { Several educational modalities exist; evaluate differences among study-abroad short } \\
\text { courses and long courses, exchange programs, and partnerships that rely on } \\
\text { technology rather than physical travel (e.g., videoconferencing in the classroom). }\end{array}$ \\
\hline $\begin{array}{l}\text { Seek mentorship and institutional } \\
\text { support }\end{array}$ & $\begin{array}{l}\text { Request guidance from experienced faculty members, students, and study-abroad } \\
\text { office. }\end{array}$ \\
\hline $\begin{array}{l}\text { Develop mutually beneficial } \\
\text { partnerships }\end{array}$ & $\begin{array}{l}\text { Focus on building partnerships that advance the objectives of partners, } \\
\text { simultaneously achieving student learning outcomes and improving international } \\
\text { community food systems. }\end{array}$ \\
\hline Make pre-trip visit & $\begin{array}{l}\text { A pre-trip site visit is advisable to understand the intricacies and logistics of the } \\
\text { program and to provide leadership when guiding students. }\end{array}$ \\
\hline $\begin{array}{l}\text { Research international agricultural } \\
\text { and food system }\end{array}$ & $\begin{array}{l}\text { Working with international partner, research the literature, and develop a list of } \\
\text { agriculture and food system topics prior to the international activity. For example, } \\
\text { students may become familiar with international agriculturally important products, } \\
\text { means of production, markets, food system issues related to sustainability, and the } \\
\text { effects of globalization. }\end{array}$ \\
\hline $\begin{array}{l}\text { Develop educational goals and } \\
\text { means of assessment }\end{array}$ & $\begin{array}{l}\text { Before the international activity, develop clear educational goals and means of } \\
\text { assessment. Develop activities (e.g., position papers, survey questions, travel } \\
\text { journals, student-led discussion, critical thinking questions, Photovoice, video and } \\
\text { audio Podcasts, and electronic portfolios) that enhance student learning outcomes, } \\
\text { promote reflection before, during, and after the trip, and provide the faculty member } \\
\text { with a means to assess student learning. }\end{array}$ \\
\hline Recognize cultural differences & $\begin{array}{l}\text { During the pre-site visit, through research, and use advice from partner to } \\
\text { understand and relay cultural differences in aspects such as food, dress, and } \\
\text { language to students. Adequately prepare students with cultural expectations. }\end{array}$ \\
\hline $\begin{array}{l}\text { Develop budget and funding } \\
\text { strategies }\end{array}$ & $\begin{array}{l}\text { Investigate various funding strategies through for-profit, nonprofit, university support, } \\
\text { governmental organizations, and scholarships. Develop a course budget that is } \\
\text { flexible and accounts for inflation and unexpected occurrences. }\end{array}$ \\
\hline
\end{tabular}

for preparing graduates to address our global food system challenges.

\section{Assessment Measures in International Sustainable Agriculture Education}

As with the development of any curriculum, clear student learning outcomes, inclusive of assessment strategies, should be developed for any international SA educational activity. A holistic approach to assessment of student learning in international education is paramount, and pedagogical methods should be evaluated for effectiveness, relevance, and impact. In addition to content-specific agricultural knowledge, these international learning experiences may also include additional learning outcomes related to cultural awareness and relativism and the development of a global perspective on SA practices and food systems. Recently in higher education there has been a growing interest in conducting assessment beyond traditional methods to more effectively assess an institution's success in meeting student learning outcomes, improving how faculty teach, and developing scholarship in teaching and learning (O'Meara, 2005).

From our collective experiences, assessment of learning outcomes in SA international education is enhanced when it is diverse and includes multiple means of student reflection, both formal and informal, to better captures the multidimensional aspects of international learning environments. Providing students multiple methods for reflection over various time periods (before, during, and after) can enhance their intercultural competence and ability to articulate their international experiences 
(Williams, 2005). Critical reflection through position papers or survey questions may also be used to assess students' cultural awareness, preconceptions, or content knowledge pre- and post-international activity. Less formal means of reflection, such as travel journals, student-led discussions, and questions of the day, also can be integrated to assess student learning throughout the international activity. Additionally, video and audio podcasts can be used in innovative ways for student assessment, in both formal and informal ways. For example, using Photovoice students can capture photos to document specific assets and issues in the community, discuss resolutions, envision future solutions, and potentially bring findings to political leaders. Photovoice is a qualitative method of reflection utilized in social science research that promotes community development and grassroots action (Wang \& Burris, 1997). Lastly, electronic portfolios can be used to foster the integration of theory, action, self-reflection, and assessment by collecting, considering, sharing, and presenting learning outcomes with and to others via a digital medium (Yancey, 2001). Through electronic portfolios, students can chronicle and share their scholastic achievements and experiences using a web-based platform.

Important to all assessments of student learning is designing activities that emphasize reflective thinking, facilitate student inquiry, encourage students to state, analyze, evaluate, and synthesize information, and that challenge students to set and work toward fulfilling learning and assessment goals for SA programs. Activities for SA international experiences are most successful when they emerge from the specific learning outcomes and inform assessment, but also are grounded in varied experiential learning opportunities (Bruening \& Shao, 2005) and engagement with diverse international partners, producers, and community members.

\section{Challenges and Opportunities}

We believe that incorporating international experiences into SA education can add substantial value to the existing curriculum. Nonetheless, developing these types of SA international learning experiences can pose very real challenges for faculty charged with establishing them. Below we describe some of the main challenges in developing SA international learning experiences: teaching to diverse audiences, the low participation by agricultural students in international experiences, knowledge of countryspecific agricultural and food systems, and faculty reward structures. We also outline some general challenges to developing international learning experiences inherent across disciplines, such as institutional support, travel and safety logistics, and cultural transitions. Within each of these challenges also exist opportunities for innovation; we present a few ideas for these based on the authors' experiences.

Teaching Diverse SA Students Internationally. While domestically based SA programs and courses may attract diverse students, some from agriculture-related majors and backgrounds as well as nontraditional students, the academic diversity among students in international SA experiences may be even greater. From our experiences, greater number of students from humanities, international studies, foreign languages, and social sciences may be attracted to participating in an international SA course. For these students this may be their first agricultural or even natural science course. It may be challenging as an educator to teach an SA course abroad at the right level to keep both students with agriculture or SA backgrounds and nonagricultural backgrounds engaged. The diversity of students and their respective backgrounds, however, can be one of the most powerful assets of a SA international course if designed with this in mind. Students can be encouraged to share their perspectives and experiences with each other before, during, and after the course through student-led discussions, paired and shared learning, and structured group exercises. In the authors' experiences, when this student diversity is treated as an asset, students gain a broader understanding of SA and food systems, in addition to an increased global perspective.

Low Participation by Agricultural Students in International Experiences. Student recruitment is one of the biggest challenges in teaching any international course, and it is a particular challenge to recruit students from agriculture and related majors. As mentioned previously, students 
in agriculture-related majors are consistently the smallest percentage of students studying abroad (IIE, 2010). While there may be many reasons for this, agriculture students may be more financially limited; in this case, scholarships can be developed to encourage their participation. In addition, opportunities (e.g., student club presentations and study-abroad seminars) can be structured for peers who previously participated in the international SA course to serve as ambassadors and reach out to these students. They may be more inclined to listen to previous student participants to discuss the personal value of international field experience.

Faculty Knowledge of SA Systems Abroad. Teaching an international SA course well requires country-specific knowledge of crop and animal management practices and food systems, in addition to the SA content. In addition, it may be difficult to observe specific crop or animal stages or production systems in short courses, depending on the time of year when the course is taught. While all of this country-specific knowledge might seem daunting to a faculty member trying to develop a new course, there are many ways to collaborate with international institutions in-country through team teaching, cross-student exchanges, and site visits suggested by international colleagues. Faculty can research existing memorandums of understanding with international partners in place at their home institutions, and seek out other faculty at their home institution or other institutions that have taught in similar countries. A reconnaissance visit prior to involving students is highly recommended to investigate in-country farm visits, institutional collaborations, activities, and lodging.

Faculty Reward Structure. As observed in the SAEA pre-conference workshop, many of the faculty leading SA programs nationwide are pretenured although developing international courses may often be discouraged for junior faculty. One overarching challenge we have observed for many junior faculty revolves around whether SA international education is valued as scholarship. Faculty engaged in international education efforts need structural assurance that their efforts are not neglected by the traditional reward systems of tenure and promotion. It is vital that faculty who are considering developing these SA international learning experiences understand how their contributions to international education align with promotion and tenure policies at their particular institution.

Literature on academic reward systems concerning faculty pursuits of international learning opportunities is limited (O’Meara, 2005). Expectations for promotion and tenure are often vague concerning the scholarship associated with international pedagogy and can be influenced by academic leadership and by messages sent at the institutional level about what should be valued and rewarded. There should be congruence between faculty priorities and the institutional goals and objectives for promotion. Furthermore, when faculty research initiatives interface in some capacity within the international setting, faculty scholarship may be more readily validated within universities. Currently there is a scarcity of systematically gathered qualitative and quantitative information that assesses the impact of international learning opportunities and study abroad, leaving a prime opportunity for faculty to research and present scholarship on the effectiveness on learning using appropriate assessment methodologies. Within the context of the university frameworks, it is important to strategically engage in dialogue that expands the criteria used to assess research expectations toward more favorable alternative forms of scholarship, including international education (Huber, 2002).

\section{General Challenges to International} Learning Experiences. We note that there are many logistical aspects to consider from the perspective of students, faculty, university administrators, and international program site organizers for any type of international program. Multiple challenges may occur before, during, and after return, which may vary depending on the length of travel and the destination. Additional aspects to consider include:

- Curriculum credit: Offering academic credit for international experiences varies across institutions and is often generic in description (e.g., independent study, study abroad, or fieldwork). However, when such opportunities are connected to a specific course, they become anchored in authentic pedagogy associated 
with assessment of student learning. In addition, a credit-based structure can help validate the experience for students and faculty. The student's academic transcript reflects the international experience and faculty are acknowledged for their scholarship in teaching the course.

- Management of time-sensitive logistics: Sufficient lead time is necessary when arranging trips regarding things such as airfare, travel, and medical insurance (required by most universities), travel prophylactic vaccinations, prescription prophylactic medication, and other country-specific matters.

- Travel finances/program length: Probably one of the greatest burdens to students is the cost of the study abroad. It can sometimes be the biggest barrier to student recruitment. Additionally, a whole semester or year abroad may be a deterrent for many students as it may disrupt or delay their academic progress toward their degree and subsequently graduation. Many college students need some level of financial assistance to participate. Numerous university offices of international studies offer scholarships or advice on other funding opportunities for international travel, for both faculty and students.

- Miscellaneous: Things often beyond our control include flight cancelations, medical emergencies, traveler's sickness, environmental or food allergies, and legal issues. For these reasons and others, significant thought must be given to contingency plans. Many institutions require this. Although there is no generic "road map" for developing or implementing a study-abroad experience, it is advisable to establish some guidelines for every step in the process. We only identify key categories, as the actual nuts and bolts are beyond the scope of this article.

Institutional Support. The quest for achieving global competence seldom addresses the specific steps or process. Ideally, successful internationalization is embedded in an institution's strategic plans and missions (McCarthy, 2007). In addition, it takes leadership and commitment from faculty, staff, students, and administrators. It typi- cally starts with a faculty member's deep desire to engage and enhance the international perspective for their students. Such faculty leaders can set into motion a cascade of events that ultimately influences institutional support. Below we give suggestions for faculty who question how to get started. Table 3 also provides further insights into building capacity to implement an abroad experience specific for SA.

Since taking responsibility for a study-abroad experience might seem initially daunting, partnering with a seasoned practitioner of international experiential learning is highly recommended. Such mentoring becomes an asset to the novice and a future resource. Just the volume of paperwork required is intimidating and needs oversight, including effective organizational planning skills on the part of the lead faculty. The timing of almost every decision is critical and certainly benefits from someone experienced in this, especially if the program of study involves students and faculty from other universities. Multi-institutional collaborations can be advantageous, but create yet another variable and layer of complexity to the travel equation. Most challenges revolve around logistics, including finances, health and safety concerns, lodging, meals, transportation within the country, reliable on-theground contacts, and language and translation. It is critically important to put these details in place well in advance of the actual travel. Campus studyabroad offices may require advanced notice of up to a year for travel to certain countries.

An institutional plan for supporting international learning must resonate with faculty, administrators, and students to be successful. Given the implicit and explicit values to SA international experiences, questions still remain about such opportunities. For example, how do we convince higher-education administrations to embed permanent funding for such SA international curricula? Deal with financial constraints? What are the measurable learning outcomes of a globally competent graduate? How do we engage more faculty members in international research and education activities?

While each institution may be separately struggling with these questions and trying to recruit enough students for the viability of each inter- 
national trip, there are many opportunities for collaboration in international learning across institutions abroad and within the U.S. When faculty and institutions collaborate on offering international courses abroad, faculty efforts in advertising, student recruitment, and course logistics can be shared. From our experiences, students can benefit from shared faculty expertise and perspectives, as well as from interactions with other students across institutions.

Language and Cultural Transitions. The distinct learning opportunities that international education provides for students to mature as global citizens also produces specific challenges, especially in relationship to culture shock or transition (Ward, Bochner, \& Furnham 2001). Examples of cultural transitioning for students abound in international education experiences, and can include broadening perceptions related to multicultural awareness, ideologies, and cultural norms. Challenges associated with culture shock can be as simple as food, language, currency exchange, and attire, or can be as complex as accepting and understanding foreign gender equality and religious practices. From our own observations, participants returning from an international experience can exhibit unexpected post-trip disequilibrium and discontent. Students express feelings such as "reverse" homesickness, the inability to explain the experience coherently, and relationship changes as ideas and attitude have been influenced by the experience. In the midst of cultural transition, there are various opportunities for students to serve as ambassadors of their international program and encourage other students to engage in international learning. Upon their return, students and faculty alike can become not only spokespersons for dissemination about the experience, but also recruiters for future trips.

\section{Concluding Thoughts}

Today, there is much more awareness and demand for international education than ever before, involving partnerships forged by a myriad of stakeholders, including government-funded agencies and foundations, nonprofit organizations, private-sector entities, institutions, and universities. We recognize that there are numerous academics of SA engaging in a variety of multidimensional international experiences for students and faculty. While these international SA experiences are programmatically varied, there are commonalities and challenges along with rewards and dynamic opportunities for building partnerships between countries and faculty and students from other universities. Furthermore, upon returning both faculty and students have an opportunity to share their experience with the wider university community. This helps to engage the interest of others as a potential recruitment tool, while helping to attract and sustain a core level of interest for future international programs. Independent of educational modality, the forms of international experiences in SA can promote the idea of global citizenship, competence in the global arena, and an understanding of SA and associated practices from a global food system perspective.

The multidisciplinary nature of SA as a discipline lends itself to participatory learning and critical thinking exercises with real-world challenges (Lieblein, Østergaard, \& Francis, 2004). LGUs need to be prepared to provide students with the skills and knowledge in SA with an international perspective that is critical to the future of our global food systems. International SA education is especially pertinent to food system learning as the current dominant food system structure relies upon globalized and industrialized techniques. The dominant food system is frequently criticized, stemming from the current negative environmental impacts (Foley et al., 2005) and failure to meet the nutritional needs of existing or future populations (Godfray et al., 2010). These concerns require a global perspective about the effects, varieties, opportunities, and challenges of agriculture types (e.g. sustainable, industrial, and civic) that exist around the world. We believe that shifting to a local, national, and international focus in SA education will better prepare students to understand their own responsibilities both in local community-based food systems and as global food citizens. Providing both local and global perspectives in all aspects of SA learning is not just important for SA programs at LGUs, but vital to all SA education programs.

Lastly, we hope this paper provides a platform for further discussion and a larger dialogue on how 
to successfully integrate international opportunities in SA education, while also emphasizing its importance. We believe a collaborative working group or consortium among SA educators currently or interested in teaching internationally is a necessary next step to facilitate the development of shared resources and materials, discuss SA content and pedagogical strategies, and develop joint research and key metrics for assessing program impacts.

\section{References}

Acker, D. (1999). Improving the quality of higher education in agriculture globally in the $21^{\text {st }}$ century: Constraints and opportunities. Journal of International Agricultural and Extension Education, 6(2), 47-53.

Brooks, S. E., Frick, M., \& Bruening, T. H. (2006). How are land grant institutions internationalizing undergraduate agriculture students? Journal of International Agricultural and Extension Education, 13(3), 91-102.

Bruening, T. H., \& Shao, X. (2005). What should be included in an international agriculture undergraduate course? Journal of International Agricultural and Extension Education, 12(1), 47-54.

Dwyer, M. M., \& Peters, C. K. (2004). The benefits of study abroad. Transitions Abroad, 27(5), 56-57.

Etling, A., \& McGirr, M. (2005). Issues and procedures in forging international university partnerships. Journal of International Agricultural and Extension Education, 12(2), 15-21.

Foley, J. A., DeFries, R., Asner, G. P., Barford, C., Bonan, G., Carpenter, S. R.,... Snyder, P. K. (2005). Global consequences of land use. Science, 309(5734), 570-574. http://dx.doi.org/10.1126/science.1111772

Godfray, H. C. J., Beddington, J. R., Crute, I. R., Haddad, L., Lawrence, D., Muir,...Toulmin, C. (2010). Food security: The challenge of feeding 9 billion people. Science, 327(5967), 812-818. http://dx.doi.org/10.1126/science. 1185383

Heffernan, T., \& Poole, D. (2005). In search of "the vibe": Creating effective international education partnerships. Higher Education, 50(2), 233-245. http://dx.doi.org/10.1007/s10734-004-6352-2

Huber, M. T. (2002). Faculty evaluation and the development of academic careers. New Directions for Institutional Research, 114, 73-84. http://dx.doi.org/10.1002/ir.48
Institute of International Education [IIE]. (2010). Open doors 2010 report on international education exchange. New York: Author. Retrieved from http://www.iie.org/opendoors

Lewin, R. (2009). Transforming the study abroad experience into a collective priority. American Association of Colleges \& Universities Peer Review, 11, 8-11.

Lieblein, G., Østergaard, E., \& Francis, C. (2004). Becoming an agroecologist through action education. International Journal of Agricultural Sustainability, 2(3), 147-153. http://dx.doi.org/10.1080/14735903.2004.9684574

McCarthy, J. S. (2007). A roadmap for creating the global campus. The Chronicle of Higher Education, 53(44), B12.

National Research Council of the National Academies [NRC]; Division on Earth and Life Studies; Board on Agriculture and Natural Resources Board on Life Sciences. (2009). Transforming agricultural education for a changing world. Washington, D.C.: The National Academies Press.

National Association of State Universities and Land Grant Colleges [NASULGC]. (2004). A call to leadership: The presidential role in internationalizing the university. Washington, D.C.: Author.

National Association of State Universities and Land Grant Colleges [NASULGC]. (2007). A national action agenda for internationalizing higher education. Washington, D.C.: Author.

O’Meara, K. A. (2005). Encouraging multiple forms of scholarship in faculty reward systems: Does it make a difference? Research in Higher Education, 46(5), 479510. http://dx.doi.org/10.1007/s11162-005-3362-6

Parr, D., Trexler, C. J., Khanna, N. R., \& Battisti, B. T. (2007). Designing sustainable agriculture education: Academics' suggestions for an undergraduate curriculum at a land grant university. Agriculture and Human Values, 24(4), 523-533. http://dx.doi.org/10.1007/s10460-007-9084-y

Thompson, B. (2009, June). Educational and training opportunities in sustainable agriculture (19th ed.). Retrieved from USDA National Agricultural Library website: http://www.nal.usda.gov/afsic/ pubs/edtr/EDTRIntlA.shtml

Tonkin, H., \& Quiroga, D. (2004). A qualitative approach to the assessment of international servicelearning. Frontiers: The Interdisciplinary Journal of Study Abroad, 10, 131-149. 
Tubbeh, L., \& Williams, J. (2010, Summer). Framing issues of international education. New Directions for Higher Education, 150, 7-16. http://dx.doi.org/10.1002/he.386

VanDerZanden, A. M., Haynes, C., Nonnecke, G. R., \& Martin, R. (2007). Attitudes and perceptions of participants in a horticulture study abroad course at Iowa State University. HortTechnology, 17, 128-132.

Wang, C., \& Burris, M. A. (1997). Photovoice: Concept, methodology, and use for participatory needs assessment. Health Education \& Behavior, 24(3), 369-387. http://dx.doi.org/10.1177/109019819702400309
Ward, C., Bochner, S., \& Furnham, A. (2001). The psychology of culture shock. (2nd ed.). East Sussex: Routledge.

Williams, T. R. (2005). Exploring the impact of study abroad on students' intercultural communication skills: Adaptability and sensitivity. Journal of Studies in International Education, 9(4), 356-371. http://dx.doi.org/10.1177/1028315305277681

Yancey, K. B. (2001). Digitized student portfolios. In B. Cambridge (Ed.), Electronic portfolios: Emerging practices in student, faculty, and institutional learning (pp. 15-30). Sterling, Virginia: Stylus. 


\section{Appendix}

Table 2. Highlighted Examples of International Sustainable Agriculture Education Courses with Program Descriptors

Lead institution(s) responsible for developing and offering the course are listed below the course name.

\begin{tabular}{|c|c|c|c|c|c|c|c|}
\hline International SA course & Location & SA Content & Activities & $\begin{array}{l}\text { Program } \\
\text { Length }\end{array}$ & $\begin{array}{l}\text { Average } \\
\text { Number of } \\
\text { Participants }\end{array}$ & $\begin{array}{l}\text { International or } \\
\text { NGO } \\
\text { Collaborations? }\end{array}$ & $\begin{array}{l}\text { Service-Learning } \\
\text { Activities? }\end{array}$ \\
\hline $\begin{array}{l}\text { Oaxaca, Mexico Semester } \\
\text { Abroad Program } \\
\text { (University of Vermont) }\end{array}$ & Mexico, Oaxaca & $\begin{array}{l}\text { Tropical farming } \\
\text { and gardening, } \\
\text { food, culture, health }\end{array}$ & $\begin{array}{l}\text { Visits to farms, hands on } \\
\text { experiential learning, inter- } \\
\text { views with practitioners }\end{array}$ & 4 months & $\begin{array}{l}12 \\
\text { undergraduate } \\
\text { students }\end{array}$ & $\begin{array}{l}\text { Unitierra, } \\
\text { Grupedesac, Ejutla }\end{array}$ & $\begin{array}{l}\text { Yes, work with partners } \\
\text { to install school and } \\
\text { community gardens }\end{array}$ \\
\hline $\begin{array}{l}\text { Organic Production and } \\
\text { Marketing in Spain } \\
\text { (University of Florida) }\end{array}$ & $\begin{array}{l}\text { Spain, Madrid } \\
\text { and Valencia }\end{array}$ & $\begin{array}{l}\text { Organic agriculture, } \\
\text { regulation, and } \\
\text { marketing }\end{array}$ & $\begin{array}{l}\text { Visits to farms, markets, } \\
\text { universities, interaction with } \\
\text { faculty, students, compare } \\
\text { organic agriculture between } \\
\text { U.S. and Europe }\end{array}$ & 1 week & $\begin{array}{l}6-10 \\
\text { undergraduate } \\
\text { students }\end{array}$ & & No \\
\hline $\begin{array}{l}\text { Season Extension } \\
\text { Horticulture in China } \\
\text { (Multi-institutional } \\
\text { collaboration among } \\
\text { Mississippi State } \\
\text { University, Texas A\&M } \\
\text { University, University of } \\
\text { Arkansas, and University } \\
\text { of Florida) }\end{array}$ & $\begin{array}{l}\text { China, various } \\
\text { locations }\end{array}$ & $\begin{array}{l}\text { Season extension, } \\
\text { production, and } \\
\text { marketing }\end{array}$ & $\begin{array}{l}\text { Visits to farms, research } \\
\text { institutes, universities, and } \\
\text { businesses; interaction with } \\
\text { faculty, researchers, and } \\
\text { students }\end{array}$ & 3 weeks & $\begin{array}{l}10 \\
\text { undergraduate } \\
\text { and graduate } \\
\text { students }\end{array}$ & & No \\
\hline $\begin{array}{l}\text { Study Tour in Honduras } \\
\text { (Virginia Tech) }\end{array}$ & $\begin{array}{l}\text { Honduras, } \\
\text { Tegucigalpa, } \\
\text { Trinidad, Copan, } \\
\text { Copantle village }\end{array}$ & $\begin{array}{l}\text { Community food } \\
\text { systems, food } \\
\text { security, food } \\
\text { sovereignty, } \\
\text { sustainable } \\
\text { development }\end{array}$ & $\begin{array}{l}\text { Multiple Heifer projects } \\
\text { visits; (Sustainable Food } \\
\text { Systems; Food Sovereignty } \\
\text { and Biodiversity; Farm } \\
\text { School) }\end{array}$ & $\begin{array}{l}7-10 \text { days, } \\
\text { with a } \\
\text { domestic } \\
\text { based } \\
\text { semester } \\
\text { course }\end{array}$ & $\begin{array}{l}10-15 \\
\text { undergraduate } \\
\text { and graduate } \\
\text { students }\end{array}$ & $\begin{array}{l}\text { Heifer } \\
\text { International, } \\
\text { partner in course } \\
\text { offering }\end{array}$ & $\begin{array}{l}\text { Yes, various farm and } \\
\text { garden school project; } \\
\text { land management } \\
\text { projects; build animal } \\
\text { facilities }\end{array}$ \\
\hline $\begin{array}{l}\text { Sustainability of Tropical } \\
\text { Agroecosystems (Multi- } \\
\text { institutional collaboration } \\
\text { between North Carolina } \\
\text { State University and } \\
\text { University of Georgia) }\end{array}$ & $\begin{array}{l}\text { Costa Rica, } \\
\text { countrywide }\end{array}$ & $\begin{array}{l}\text { Introductory sus- } \\
\text { tainable agriculture, } \\
\text { tropical crop and } \\
\text { animal production, } \\
\text { processing and } \\
\text { marketing, conser- } \\
\text { vation of natural } \\
\text { resources }\end{array}$ & $\begin{array}{l}\text { Visits to farms, businesses, } \\
\text { national parks universities, } \\
\text { interactions with faculty, } \\
\text { researchers and students, } \\
\text { home stays, group projects } \\
\text { developing farm level } \\
\text { indicators of sustainability }\end{array}$ & 3 weeks & $\begin{array}{l}12-20 \\
\text { undergraduate } \\
\text { and graduate } \\
\text { students }\end{array}$ & $\begin{array}{l}\text { Site visits with } \\
\text { EARTH, CATIE, } \\
\text { UCR }\end{array}$ & $\begin{array}{l}\text { Yes, few, work with } \\
\text { EARTH and } \\
\text { surrounding } \\
\text { community to help } \\
\text { build a biodigestor, } \\
\text { plant tress }\end{array}$ \\
\hline
\end{tabular}




\begin{tabular}{|c|c|c|c|c|c|c|c|}
\hline $\begin{array}{l}\text { Sustainable Food, } \\
\text { Environment \& Social } \\
\text { Systems in Australia } \\
\text { (Michigan State } \\
\text { University) }\end{array}$ & $\begin{array}{l}\text { Australia, south } \\
\text { and eastern } \\
\text { coasts }\end{array}$ & $\begin{array}{l}\text { Introductory } \\
\text { sustainability and } \\
\text { human impacts on } \\
\text { environment in the } \\
\text { context of food }\end{array}$ & $\begin{array}{l}\text { Visits to farms, agribusi- } \\
\text { nesses, research and } \\
\text { processing facilities; field } \\
\text { work, independent research } \\
\text { project }\end{array}$ & $\begin{array}{l}4 \text { weeks, } \\
\text { with } 6-10 \\
\text { domestic- } \\
\text { based } \\
\text { sessions }\end{array}$ & $\begin{array}{l}15-25 \\
\text { undergraduate } \\
\text { students }\end{array}$ & $\begin{array}{l}\text { Collaborate with } \\
\text { several universi- } \\
\text { ties, companies, } \\
\text { and research } \\
\text { facilities, varies } \\
\text { year to year }\end{array}$ & $\begin{array}{l}\text { Yes, 2-3 projects each } \\
\text { year; teach at school, } \\
\text { weeding and planting } \\
\text { in the rainforest, or } \\
\text { wetland regeneration. }\end{array}$ \\
\hline
\end{tabular}

